\title{
Inhibitory effect of okadaic acid on the p-nitrophenyl phosphate phosphatase activity of protein phosphatases
}

\author{
Akira TAKAI* $\ddagger$ and Gottfried MIESKES $\dagger$ \\ *Department of Physiology, School of Medicine, Nagoya University, Tsurumai-cho 65, Showa-ku, Nagoya 466, Japan, and \\ †Abteilung Klinische Biochemie, Zentrum für Innere Medizin, Universität Göttingen, Göttingen, Federal Republic of Germany
}

\begin{abstract}
The phosphatase activities of type $2 \mathrm{~A}$, type 1 and type $2 \mathrm{C}$ protein phosphatase preparations were measured against $p$-nitrophenyl phosphate ( $p$ NPP), a commonly used substrate for alkaline phosphatases. Of the three types of phosphatase examined, the type $2 \mathrm{~A}$ phosphatase exhibited an especially high $p$ NPP phosphatase activity $(119 \pm 8 \mu \mathrm{mol} / \mathrm{min} \mathrm{per} \mathrm{mg}$ of protein; $n=4)$. This activity was strongly inhibited by pico- to nano-molar concentrations of okadaic acid, a potent inhibitor of type $2 \mathrm{~A}$ and type 1 protein phosphatases that has been shown to have no effect on alkaline phosphatases. The dose-inhibition relationship was markedly shifted to the right and became steeper by increasing the concentration of the enzyme, as predicted by the kinetic theory for tightly binding inhibitors. The enzyme concentration estimated by titration with okadaic acid agreed well with that calculated from the protein content and the molecular mass for type $2 \mathrm{~A}$ phosphatase. These results strongly support the idea that the $p$ NPP phosphatase activity is intrinsic to type $2 \mathrm{~A}$ protein phosphatase and is not due to contamination by alkaline phosphatases. $p$ NPP was also dephosphorylated, but at much lower rates, by type 1 phosphatase $(6.4 \pm 8 \mathrm{nmol} / \mathrm{min}$ per $\mathrm{mg}$ of protein; $n=4)$ and type $2 \mathrm{C}$ phosphatase $(1.2 \pm 3 \mathrm{nmol} / \mathrm{min}$ per $\mathrm{mg}$ of protein; $n=4)$. The $p \mathrm{NPP}$ phosphatase activity of the type 1 phosphatase preparation shows a susceptibility to okadaic acid similar to that of its protein phosphatase activity, whereas it was interestingly very resistant to inhibitor 2 , an endogenous inhibitory factor of type 1 protein phosphatase. The $p$ NPP phosphatase activity of type 2C phosphatase preparation was not affected by up to $10 \mu \mathrm{M}$-okadaic acid.
\end{abstract}

\section{INTRODUCTION}

It is now generally accepted that most, if not all, of the phosphoseryl/phosphothreonyl phosphatases in the cytoplasmic compartments of eukaryotic cells can be accounted for by four different catalytic subunits (types 1, 2A, 2B and 2C; Ingebritsen \& Cohen, 1983; for a review see Cohen, 1989). Although these major protein phosphatases have little or no activity towards phosphorylated compounds of low molecular mass, several previous investigators have reported protein phosphatase preparations which are able to dephosphorylate $p$-nitrophenyl phosphate ( $p$ NPP), a commonly used substrate for alkaline phosphatases (see $\mathrm{Li}, 1982$ ). However, it is not clear in most of the cases whether such $p$ NPP phosphatase activities are ascribable to a broad substrate specificity of the protein phosphatases or to contamination by alkaline phosphatases. So far, it has not been established whether or not type 1 , type $2 \mathrm{~A}$ and type $2 \mathrm{C}$ protein phosphatases have intrinsic $p$ NPP phosphatase activities. Exceptionally, $p$ NPP is accepted as a substrate for the assay of type 2B phosphatase (= calcineurin), whose $p$ NPP phosphatase activity has been shown to have close similarities to the protein phosphatase activity in $\mathrm{pH}$-dependence as well as in requirement for $\mathrm{Ca}^{2+}$ and calmodulin (Pallen \& Wang, 1983).

Okadaic acid, a polyether fatty acid, first isolated from the marine sponges of the genus Halichondria (Tachibana et al., 1981), has been reported to have a potent inhibitory effect on protein phosphatases (Takai et al., 1987; Bialojan \& Takai, 1988). Studies using purified enzymes (Hescheler et al., 1988; Bialojan \& Takai, 1988; Haystead et al., 1989) have shown that the substance has an especially high affinity to the catalytic subunits of type $2 \mathrm{~A}$ and type 1 phosphatases, which are structurally related enzymes having $50 \%$ amino acid sequence identity in the catalytic domain (Cohen, 1989; Cohen \& Cohen, 1989).
Type 2B phosphatase is inhibited to a much lesser extent, whereas type $2 \mathrm{C}$ phosphatase is not affected by okadaic acid (Bialojan \& Takai, 1988). It has been shown that okadaic acid has no effect on alkaline phosphatases (Bialojan \& Takai, 1988). The following phosphatases are also unaffected by up to $10 \mu \mathrm{M}$ okadaic acid: acid phosphatases, phosphotyrosyl phosphatases, inositol 1,4,5-trisphosphate phosphatase (Bialojan \& Takai, 1988).

In the present experiments we measured the $p$ NPP phosphatase activities of type 1, type $2 \mathrm{~A}$ and type $2 \mathrm{C}$ phosphatases and examined their susceptibilities to okadaic acid and inhibitor 2 , an endogenous inhibitory factor of type 1 phosphatase (Huang \& Glinsmann, 1976; Cohen et al., 1977). We report here that the type $2 \mathrm{~A}$ phosphatase has an exceedingly high $p$ NPP phosphatase activity, whose sensitivity to okadaic acid is very similar to that of its protein phosphatase activity. We also show that the type 1 phosphatase exhibits a weak $p$ NPP phosphatase activity with sensitivity to okadaic acid. Interestingly, the $p$ NPP phosphatase activity of type 1 phosphatase is resistant to inhibitor 2 .

\section{EXPERIMENTAL}

\section{Materials}

Okadaic acid, isolated from the black sponge Halichondria okadai, was kindly given by Dr. Y. Tsukitani (Fujisawa Pharmaceutical Co., Tokyo, Japan). $\left[\gamma^{-{ }^{32}}\right.$ P $]$ ATP was obtained from NEN. All other chemical reagents, including $p N P P$, were products of Sigma Chemical Co.

\section{Preparation of protein phosphatases and inhibitor 2}

The catalytic subunits of type $2 \mathrm{~A}$ and type 1 protein phosphatases were prepared from rabbit skeletal muscle as described by Tung et al. (1984). SDS/polyacrylamide-gel 
electrophoresis of these enzymes revealed single protein bands with apparent molecular mass of $36-37 \mathrm{kDa}$. The type $2 \mathrm{C}$ phosphatase was purified from rabbit liver by the method of McGowan \& Cohen (1987). Inhibitor 2 was purified from rabbit skeletal muscle as described by Cohen et al. (1988).

The concentrations of proteins were determined by the method described by Lowry et al. (1951).

\section{Preparation of substrates}

$p$ NPP (disodium salt) was dissolved in buffer solution just before use. Myosin light chains were isolated from chicken gizzard as described by Cummins \& Lambert (1986) and $\left[{ }^{32} \mathrm{P}\right]$ phosphorylated by using myosin light-chain kinase from chicken gizzard (Ngai et al., 1984). Preparation of ${ }^{32}$ P-labelled phosphorylase $a$ was as described by Cohen et al. (1988).

\section{Assay of phosphatase activities}

All assays were carried out at $30^{\circ} \mathrm{C}$. Unless otherwise mentioned, reaction mixtures contained $40 \mathrm{~mm}-\mathrm{Tris} / \mathrm{HCl}$, $20 \mathrm{~mm}-\mathrm{KCl}, 30 \mathrm{~mm}-\mathrm{MgCl}_{2}$ and $2 \mathrm{~mm}$-DL-dithiothreitol ( $\mathrm{pH} 8.1$ at $30^{\circ} \mathrm{C}$ ). Enzymes were diluted with this buffer supplemented with $1 \mathrm{mg}$ of $\mathrm{BSA} / \mathrm{ml}$. When the concentration of $\mathrm{Mg}^{2+}$ was changed, the ionic strength was kept constant at $0.13 \mathrm{M}$ by changing the concentration of $\mathrm{KCl}$. For assays of type 1 phosphatase, $1 \mathrm{~mm}-\mathrm{MnCl}_{2}$ was added. To assay $p \mathrm{NPP}$ phosphatase activities, reaction was started by addition of enzyme and the initial rate of liberation of $p$-nitrophenol was measured by recording the change in absorbance at $400 \mathrm{~nm}$ with a pen recorder. Phosphorylated myosin light-chain (PMLC) phosphatase activity and phosphorylase $a$ phosphatase activity were assayed by our standard procedure (Takai et al., 1989).

Okadaic acid was dissolved in dimethyl sulphoxide (DMSO) to give a $10 \mathrm{~mm}$ solution and diluted in aqueous buffers. The maximal concentration of DMSO in reaction mixtures was $0.01 \%(v / v)$. Control activities were not significantly affected by addition of this amount of DMSO.

\section{Dose-inhibition relationships}

When the affinity of an inhibitor to an enzyme is high, a significant fraction of the inhibitor molecule in the reaction mixture is bound to the enzyme. This situation becomes particularly marked when the enzyme concentration is relatively high. The concentration of free inhibitor, $I_{p}$, and that of enzymebound inhibitor, $I_{\mathrm{b}}$, are given by the following equations (see Henderson, 1972):

and

$$
I_{\mathrm{f}}=K_{\mathrm{i}}\left[\left(v_{0} / v_{\mathrm{i}}\right)-1\right]
$$

$$
I_{\mathrm{b}}=E_{\mathrm{t}}\left[1-\left(v_{\mathrm{i}} / v_{0}\right)\right]
$$

where $K_{\mathrm{i}}\left[=K_{\mathrm{i}}(s)\right]$ is the apparent dissociation constant for the inhibitor which is in general a function of the substrate concentration, $s$ [see eqn. (9) below], $E_{\mathrm{t}}$ is the total concentration of the enzyme, and $v_{0}$ and $v_{i}$ are the initial steady-state velocities of the reaction in the absence and presence of the inhibitor respectively. The conservation equation for the inhibitor is

$$
I_{\mathrm{t}}=I_{\mathrm{f}}+I_{\mathrm{b}}
$$

where $I_{\mathrm{t}}$ is the total concentration of the inhibitor. Inserting eqns. (1) and (2) into (3), we obtain the following quadratic equation for the fractional activity, $v_{\mathrm{i}} / v_{0}$ :

$$
E_{\mathrm{t}}\left(v_{\mathrm{i}} / v_{0}\right)^{2}+\left(I_{\mathrm{t}}-E_{\mathrm{t}}+K_{\mathrm{i}}\right)\left(v_{\mathrm{i}} / v_{0}\right)-K_{\mathrm{i}}=0
$$

Solving eqn. (4), we have

$$
v_{\mathrm{i}} / v_{0}=\left[\left(E_{\mathrm{t}}-I_{\mathrm{t}}-K_{\mathrm{i}}\right)+\sqrt{\left(E_{\mathrm{t}}-I_{\mathrm{t}}-K_{\mathrm{i}}\right)^{2}+4 E_{\mathrm{t}} K_{\mathrm{i}}}\right] / 2 E_{\mathrm{t}}
$$

In the present experiments, we used this equation to fit the dose-inhibition relationships for the $p$ NPP phosphatase activity of the type $2 \mathrm{~A}$ protein phosphatase.

\section{Estimation of $\boldsymbol{K}_{\mathbf{i}}$}

The concentration of the inhibitor required to obtain $50 \%$ inhibition, $\mathrm{ID}_{50}$, is given by eqn. (4) as the value of $I_{t}$ at which $v_{\mathrm{i}} / v_{0}=0.5$; i.e.

$$
\mathrm{ID}_{50}=K_{\mathrm{i}}(s)+\left(E_{\mathrm{t}} / 2\right)
$$

The value of $K_{\mathrm{i}}(s)$ can be estimated by using this relation, if the $\mathrm{ID}_{50}$ is experimentally determined for a known value of $E_{\mathrm{t}}$. Note that $E_{\mathrm{t}} / K_{\mathrm{i}}$ should be as small as possible for accurate estimation of $K_{\mathrm{i}}$ by this method.

When $E_{\mathrm{t}} / K_{\mathrm{i}}=0, I_{\mathrm{f}}$ tends to $I_{\mathrm{t}}$, and hence eqn. (1) becomes

$$
v_{\mathrm{i}} / v_{0}=K_{\mathrm{i}} /\left(K_{\mathrm{i}}+I_{\mathrm{t}}\right)
$$

This is a Hill function with a Hill coefficient of 1.0.

\section{Estimation of the molar concentration of enzyme}

To use the above equations, the concentration of enzyme, $E_{t}$, must be given in terms of molar units. The molar concentration of enzyme can be estimated by 'titrating' the enzyme activity with a tightly binding inhibitor.

As pointed out by Goldstein (1944), when $E_{\mathrm{t}} / K_{\mathrm{i}}>100$ (and $I_{\mathrm{t}}$ $<E_{\mathrm{t}}$ ), virtually all of the inhibitor molecules are bound to the enzyme; i.e. $I_{\mathrm{t}}=I_{\mathrm{b}}$. Therefore, eqn. (2) becomes

$$
v_{\mathrm{i}} / v_{0}=1-\left(I_{\mathrm{t}} / E_{\mathrm{t}}\right)
$$

In the present study, we used this relation to estimate the molar concentration of the type $2 \mathrm{~A}$ protein phosphatase.

\section{Analysis of the mode of inhibition}

When the ratio $E_{\mathrm{t}} / K_{\mathrm{i}}$ is 0.01 or more, as was the case in our present study for the type $2 \mathrm{~A}$ protein phosphatase, the Michaelis-Menten analysis of the mechanism of enzyme inhibition is not valid (Goldstein, 1944; Williams \& Morrison, 1979). However, the mode of inhibition can still be diagnosed by examining the dependence of the apparent dissociation constant, $K_{1}$, on the substrate concentration, $s$.

$K_{\mathrm{i}}\left[=K_{\mathrm{i}}(s)\right]$ is a function of $s$, whose form is dependent on the type of inhibition.

(i) If an inhibitor causes mixed inhibition, $K_{1}(s)$ is given by the general form

$$
K_{\mathrm{i}}(s)=K_{0}\left[1+\left(s / K_{\mathrm{m}}\right)\right] /\left[1+\left(K_{0} / K_{1}\right)\left(s / K_{\mathrm{m}}\right)\right]
$$

where $K_{\mathrm{m}}$ is the Michaelis constant, and $K_{0}$ and $K_{1}$ are the dissociation constants of the inhibitor to free enzyme and enzyme-substrate complex respectively (see Williams \& Morrison, 1979).

(ii) Non-competitive inhibition is a special case, where $K_{0}=$ $K_{1}$, and therefore eqn. (9) reduces to

$$
K_{i}(s)=K_{0}=K_{1} \text { (constant) }
$$

(iii) With competitive inhibition $K_{1}$ equals infinity, so that eqn. (9) becomes

$$
K_{\mathrm{i}}(s)=K_{0}\left[1+\left(s / K_{\mathrm{m}}\right)\right]
$$

(iv) With uncompetitive inhibition, $K_{0}$ equals infinity and eqn. (9) becomes

$$
K_{\mathrm{i}}(s)=K_{1}\left[1+\left(K_{\mathrm{m}} / s\right)\right]
$$

Note that $K_{\mathrm{i}}$ becomes constant for non-competitive inhibitors only.

The following two points should be noted in experimental analyses of the dependence of $K_{\mathrm{i}}$ on $s$. (a) As the values of $K_{1}(s)$ are estimated indirectly from $\mathrm{ID}_{50}$ by using eqn. (6), $E_{\mathrm{t}}$ should be as small as possible. (b) Dose-inhibition relationships must be 
examined for a relatively wide range of $s$ so that the difference of the form of $K_{\mathrm{i}}(s)$ can be reliably distinguished.

\section{Statistics}

The kinetic constants of enzyme reactions were determined by the direct-linear-plot method (Eisenthal \& Cornish-Bowden, 1974), and compared by a non-parametric method (Hollander \& Wolfe, 1973) as described by Porter \& Trager (1977) by using computer programs. The values of the constants were presented with $95 \%$ confidence limits. The other numerical data were described as means \pm S.E.M., and differences were assessed by Student's $t$ test. The values of the apparent dissociation constant $K_{\mathrm{i}}$ for type $2 \mathrm{~A}$ phosphatase were estimated by fitting the dose-inhibition relationships to eqn. (5) by a non-linear leastsquares method with the use of a computer program. The dose-inhibition relationships for type 1 phosphatase were fitted by the linear least-squares method to the linear form of the Hill function :

$$
\ln \left\{\left[1-\left(v_{\mathrm{i}} / v_{0}\right)\right] /\left(v_{\mathrm{i}} / v_{0}\right)\right\}=h \cdot \ln I_{\mathrm{t}}-\ln K_{\mathrm{h}}
$$

where $h$ is the Hill coefficient and $K_{\mathrm{h}}$ is the dissociation constant. The values in the range $0.1<v_{\mathrm{i}} / v_{0}<0.9$ were used for the fitting. The values of $h$ and $K_{\mathrm{h}}$ were compared by a method of co-variance analysis (Snedecor \& Cochran, 1980). In every case, differences were evaluated as statistically significant when a two-tailed probability of less than 0.05 was obtained.

\section{RESULTS}

\section{pNPP phosphatase activity of protein phosphatases}

Table 1 gives the activities of the protein phosphatase preparations against $p$ NPP (5 mM) and phosphorylated chicken gizzard myosin light chain $(4 \mu \mathrm{M})$. All three types of preparation dephosphorylated. $p$ NPP but specific activity differed markedly among them. The type $2 \mathrm{~A}$ phosphatase had an especially high $p$ NPP phosphatase activity, which was about nine times higher than its PMLC phosphatase activity. The type 1 and type 2C phosphatases exhibited much lower $p$ NPP phosphatase activities.

Fig. 1 shows the $\mathrm{pH}$-dependence of the $p$ NPP phosphatase activity of the type $2 \mathrm{~A}$ phosphatase preparation in the presence of $30 \mathrm{~mm}-\mathrm{Mg}^{2+}$. The optimal $\mathrm{pH}$ value for the activity was in the range 8.0-8.5. Similar $\mathrm{pH}$-activity profiles with the $\mathrm{pH}$ optimum around 8.0-8.5 were obtained for the type 1 and type $2 \mathrm{C}$ phosphatase preparations. In contrast, the protein phosphatases exhibited relatively broad $\mathrm{pH}$ profiles, having the maximum at pH 6.5-7.5 when either PMLC or phosphorylase $a$ was used as substrate. The phosphorylase $a$ phosphatase activity of the type $2 \mathrm{~A}$ phosphatase at $\mathrm{pH} 7.0,8.0$ and 8.5 was $23.6 \pm 2.0,17.6 \pm 1.6$ and $11.7 \pm 1.3 \mathrm{nmol}$ of $\mathrm{P}_{\mathrm{i}} / \mathrm{min}$ per $\mathrm{mg}$ of protein $(n=3)$ respectively.

When $\mathrm{Mg}^{2+}$ was removed from the reaction mixture, the $p$ NPP phosphatase activity of the type $2 \mathrm{~A}$ phosphatase preparation was decreased to $2.3 \pm 0.6 \%(n=4)$ of the value obtained in the presence of $30 \mathrm{~mm}-\mathrm{Mg}^{2+}$. The type 1 and type $2 \mathrm{C}$ phosphatase preparations lost the $p$ NPP phosphatase activities when $\mathbf{M g}^{2+}$ was removed from reaction mixtures. Thus the $p$ NPP phosphatase activities of the protein phosphatase preparations show essentially absolute requirement for $\mathrm{Mg}^{2+}$. The $\mathrm{Mg}^{2+}$ concentration required for half-maximal activation of the $p$ NPP phosphatase activities of the type $2 \mathrm{~A}$, type 1 and type $2 \mathrm{C}$ phosphatase preparations were $25 \mathrm{~mm}, 30 \mathrm{~mm}$ and $5 \mathrm{~mm}$ respectively.

\section{Dose-inhibition relationships}

As shown in Fig. 2, the $p$ NPP phosphatase activity of the type 2A phosphatase preparation was strongly inhibited by okadaic acid. The assays were done for various concentrations $(1.9 \mathrm{ng}-0.96 \mu \mathrm{g}$ of protein $/ \mathrm{ml}$ or $50 \mathrm{pm}-25 \mathrm{nM}$ ) of the enzyme by using 5 mM-pNPP as substrate. (For determination of the molar concentration of the enzyme, see below.) The dose-inhibition curve shifted to the right and became steeper as the enzyme concentration was increased from $50 \mathrm{pm}$ to $25 \mathrm{nM}$. Similar phenomena have been reported for the inhibition of the phosphorylase $a$ phosphatase activity of type 2A phosphatase by okadaic acid (Cohen et al., 1989).

When the enzyme concentration was $50 \mathrm{pM}$, the $\mathrm{ID}_{50}$ of the dose-inhibition relationship was $57 \mathrm{pM}$, from which the dissociation constant, $K_{i}$, for the interaction between okadaic acid and the enzyme molecules was estimated, by using eqn. (6), to be $32 \mathrm{pm}$ (see the Experimental section). Thus the value of $K_{\mathrm{i}}$ is smaller than the enzyme concentrations $\left(E_{t}\right)$ under the present assay conditions $\left(1.6<E_{\mathrm{t}} / K_{\mathrm{i}}<780\right)$. The estimation of $K_{1}$ appears to be adequate, because the dose-inhibition relationships for various enzyme concentrations $\left(E_{t}\right)$ were very well fitted to eqn. (5) by using the value of $K_{\mathrm{i}}$ (Fig. 2).

\section{Table 1. Activities of the protein phosphatase preparations}

The activities of the protein phosphatase preparations were assayed against PMLC (4 $\mu \mathrm{M})$ as well as against $p$ NPP $(5 \mathrm{~mm})$. The $\mathrm{pH}$ of the reaction mixtures was 7.4 for PMLC, whereas it was 8.1 for $p$ NPP. All assays were done in the presence of $30 \mathrm{mM}-\mathrm{Mg}^{2+}$. Number of experiments, $n=4$. Definition: unit $=\mu \mathrm{mol} / \mathrm{min}$.

\begin{tabular}{ccc}
\hline $\begin{array}{c}\text { Type of } \\
\text { phosphatase }\end{array}$ & Substrate & $\begin{array}{c}\text { Activity } \\
\text { (units } / \mathrm{mg} \\
\text { of protein) }\end{array}$ \\
\hline A & $p$ NPP & $119 \pm 8$ \\
$2 \mathrm{~A}$ & PMLC & $13 \pm 1$ \\
1 & $p$ NPP & $0.064 \pm 0.008$ \\
1 & PMLC & $0.53 \pm 0.04$ \\
$2 \mathrm{C}$ & $p$ NPP & $0.012 \pm 0.03$ \\
$2 \mathrm{C}$ & PMLC & $4.0 \pm 0.3$
\end{tabular}

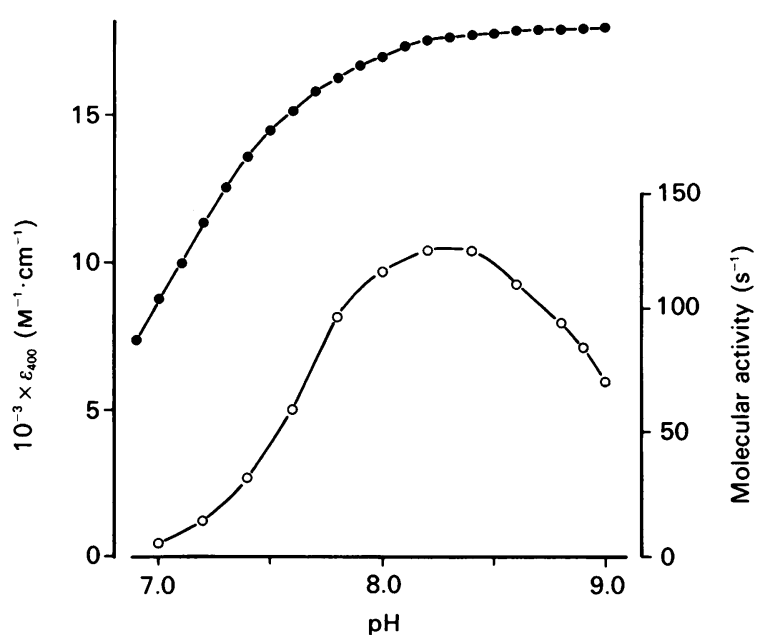

Fig. 1. pH-dependence of the $p$ NPP phosphatase activity of the type $2 \mathrm{~A}$ phosphatase

The $p$ NPP activity of the type $2 \mathrm{~A}$ phosphatase preparation was measured in the $\mathrm{pH}$ range $7.0-9.0$ in the presence of $30 \mathrm{mM}-\mathrm{Mg}^{2+}$. The ionic strength of the buffer was kept constant at $0.13 \mathrm{M}$. The activities $(O)$ were calculated by using the molar absorption coefficient for $p$-nitrophenol at $400 \mathrm{~nm}\left(\epsilon_{400} ; \ominus\right)$ for the $\mathrm{pH}$ at which the assays were made. The values are presented as molecular activities $\left(\mathrm{s}^{-1}\right)$ based on the molar concentration of the enzyme estimated by titration with okadaic acid (see Fig. 3). Each point represents the average of two values. See the text for further explanation. 


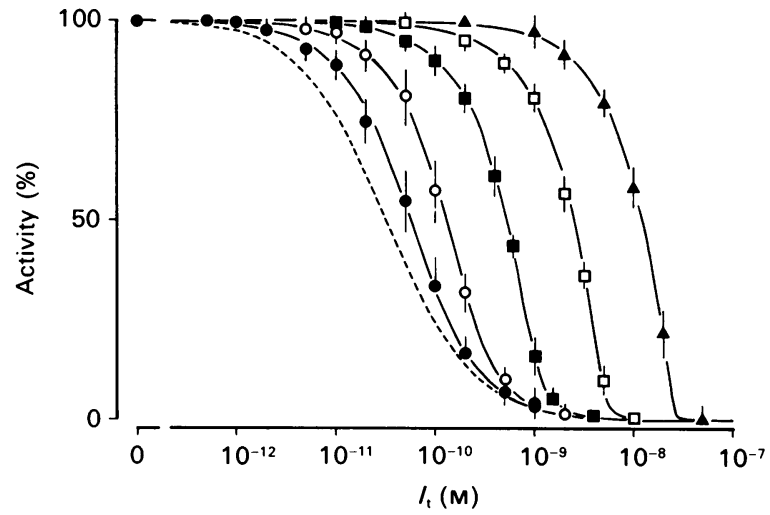

Fig. 2. Inhibition of the $p$ NPP phosphatase activity of the type $2 A$ phosphatase preparation of okadaic acid

Dose-inhibition relationships. The effect of okadaic acid was examined on various concentrations of the enzyme, $E_{\mathrm{t}}$ :, $50 \mathrm{pM}$; $\bigcirc, 200 \mathrm{pm} ; \mathbf{\square}, 1 \mathrm{nM} ; \square, 5 \mathrm{nM} ; \boldsymbol{\Delta}, 25 \mathrm{~nm}$ (for determination of the molar concentration of the enzyme, see Fig. 3). $I_{t}$ stands for the total concentration of the inhibitor [okadaic acid]. The dose-inhibition curve shifted to the right and became steeper as $E_{\mathrm{t}}$ was increased. The results were well fitted to eqn. (5) by using the value (32 pM) of $K_{\mathrm{i}}$ estimated from the results for $E_{\mathrm{t}}=50 \mathrm{pM}$. The curve given by eqn. (7) is included (dashed line) to show the left limit (i.e. $E_{\mathrm{t}} / K_{\mathrm{i}} \rightarrow 0$ ). Number of experiments, $n=4-5$. See the text for further explanations.

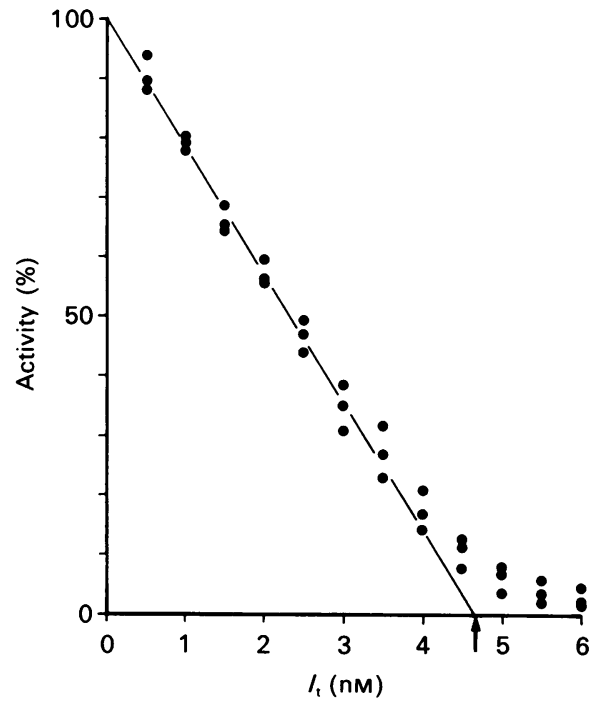

Fig. 3. Estimation of the enzyme concentration by titration with okadaic acid

The inhibitory effect of okadaic acid was examined on the $p$ NPP phosphatase activity of a relatively high concentration $(0.18 \mu \mathrm{g} / \mathrm{ml})$ of the type $2 \mathrm{~A}$ phosphatase preparation. The relative activity (\%) was plotted against the total concentration of okadaic acid applied $\left(I_{t}\right)$. The concentration of substrate $[p N P P]$ was $1 \mathrm{mM}$. Okadaic acid was cumulatively added to the cuvette. The activities are presented as percentages of the value obtained in the absence of okadaic acid. Note the linear appearance of the dose-inhibition relationship [cf. eqn. (8)]. The concentration of the enzyme responsible for the $p$ NPP phosphatase activity was estimated by extrapolation of the linearity to the abscissa (arrow) to be $4.7 \mathrm{~nm}$. See the text for further explanations.

Fig. 3 shows the relation between the concentration of okadaic acid, $I_{\mathrm{t}}$, and the fractional activity, $v_{\mathrm{i}} / v_{0}$ (in $\%$ ), for the $p \mathrm{NPP}$ $(5 \mathrm{mM})$ phosphatase activity of a relatively high concentration $(0.18 \mu \mathrm{g}$ of protein $/ \mathrm{ml}=5 \mathrm{nM}$; see below) of the type $2 \mathrm{~A}$ phosphatase preparation. [Note that the abscissa $\left(I_{t}\right)$ is linearly scaled.] Kinetic considerations predict that the plot of $v_{1} / v_{0}$ against $I_{\mathrm{t}}$ tends to be linear when $E_{\mathrm{t}} \gg K_{\mathrm{i}}$ [see the Experimental section; eqn. (8)]. In accordance with this prediction, the dose-inhibition relationship obtained gave a linear appearance in the range $0 \mathrm{nM}<I_{\mathrm{t}}<3 \mathrm{nM}$ (Fig. 3). [The deviation from linearity in the higher concentration range of okadaic acid is due to decrease in the concentration of free enzyme caused by binding with okadaic acid.] By extrapolating the linearity to the abscissa, the molar concentration of the enzyme responsible for the $p$ NPP phosphatase activity was estimated to be $4.7 \mathrm{nM}$ [see eqn. (8)], a value in close agreement with the concentration ( $5 \mathrm{nM}$ ) of the type $2 \mathrm{~A}$ phosphatase itself calculated from the protein content and the molecular mass $(35.6 \mathrm{kDa}$; Cohen, 1989). This result strongly supports the idea that the $p$ NPP phosphatase activity is intrinsic to the type 2A phosphatase. (All molar concentrations of the type $2 \mathrm{~A}$ phosphatase used in this paper are based on the concentration determined by titration with okadaic acid.)

As shown in Fig. 4, the $p$ NPP phosphatase activity of the type 1 phosphatase preparation was also inhibited by okadaic acid. The concentration of the enzyme was $20 \mu \mathrm{g}$ of protein $/ \mathrm{ml}$. About $12 \%$ of the control activity was inhibited by addition of $0.1-0.5$ nM-okadaic acid, probably because of contamination by a small amount of type 2A phosphatase, which has much higher specific activity against $p$ NPP than does type 1 phosphatase (Table 1). The activities presented have therefore been normalized to the value in the presence of $0.5 \mathrm{nM}$-okadaic acid $(88 \pm 4 \%$ of the activity in the absence of okadaic acid; $n=10$ ). The dose-inhibition relationship was fitted to a simple Hill function ( $k_{\mathrm{i}}=145 \mathrm{nM}$; the Hill coefficient, $h=0.90$ ), and this was not significantly changed when the concentration of the enzyme was decreased to $2 \mu \mathrm{g}$ of protein $/ \mathrm{ml}$ (result not shown). This result indicates that the enzyme concentration $\left(E_{\mathrm{t}}\right)$ is smaller than the $K_{\mathrm{i}}$ [see the Experimental section; eqn. (7)].

The $p$ NPP phosphatase activity of the type $2 \mathrm{C}$ phosphatase preparation was not affected by up to $10 \mu \mathrm{M}$-okadaic acid.

\section{Effect of inhibitor 2}

The effect of inhibitor 2 was examined on the PMLC phosphatase activity as well as on the $p$ NPP phosphatase activity of the type 1 phosphatase. When PMLC was used as substrate, the enzyme was preincubated in the buffer solution in either the absence or presence of inhibitor 2 for $15 \mathrm{~min}$ before the reaction was started by addition of PMLC. When $p$ NPP was used as substrate, the reaction was started without preincubation with inhibitor 2, and, after the control activity was measured, inhibitor 2 was injected into the reaction mixture. The rate of reaction was observed for at least $15 \mathrm{~min}$ after injection of inhibitor 2 . Inhibitor 2 (100 nM) suppressed the PMLC phosphatase activity of the type 1 enzyme by $96 \pm 3 \%(n=5)$, whereas it inhibited the activity $p$ NPP by only $4 \pm 2 \%(n=5)$.The activity on $p$ NPP was decreased by only $17 \pm 4 \%(n=4)$ even when the concentration of inhibitor 2 was increased to $500 \mathrm{nM}$. It has been reported that inactivation of some forms of type 1 phosphatase by inhibitor 2 is time-dependent (Strålfors et al., 1985). However, no progressive suppression was observed when the reaction rate was monitored for longer than $15 \mathrm{~min}$.

The $p$ NPP phosphatase activities of the type $2 \mathrm{~A}$ and type $2 \mathrm{C}$ phosphatase were not affected by up to 100 nM-inhibitor 2 .

\section{Kinetic analyses}

For the $p$ NPP phosphatase activity of type $2 \mathrm{~A}$ phosphatase in the absence of okadaic acid, the plot of the reciprocal of the initial steady-state velocity against that of the substrate concentration (i.e. the Lineweaver-Burk plot) had a linear appear- 


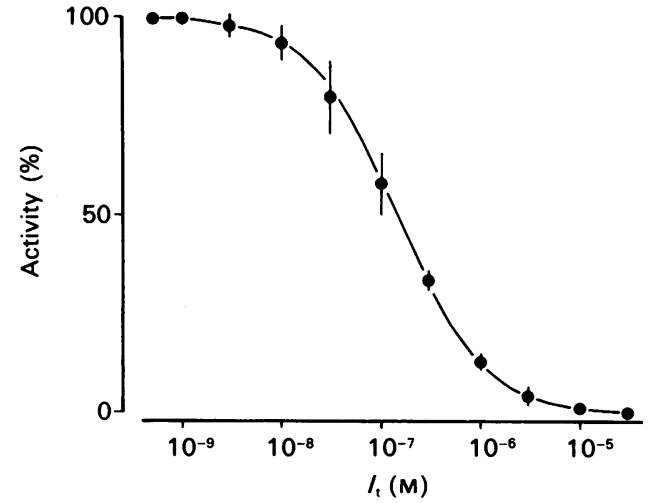

Fig. 4. Inhibition of the $p$ NPP phosphatase activity of the type 1 phosphatase preparation by okadaic acid

Dose-inhibition relationship: $I_{\mathrm{t}}$ denotes the total concentration of okadaic acid added to the cuvette. The concentrations of the enzyme and the substrate ( $p$ NPP) were $20 \mu \mathrm{g}$ of protein $/ \mathrm{ml}$ and $5 \mathrm{~mm}$ respectively. The activities are given as percentages of the value obtained in the presence of $0.5 \mathrm{~nm}$-okadaic acid. The curve is the least-squares fit to the Hill function. See the text for further details.

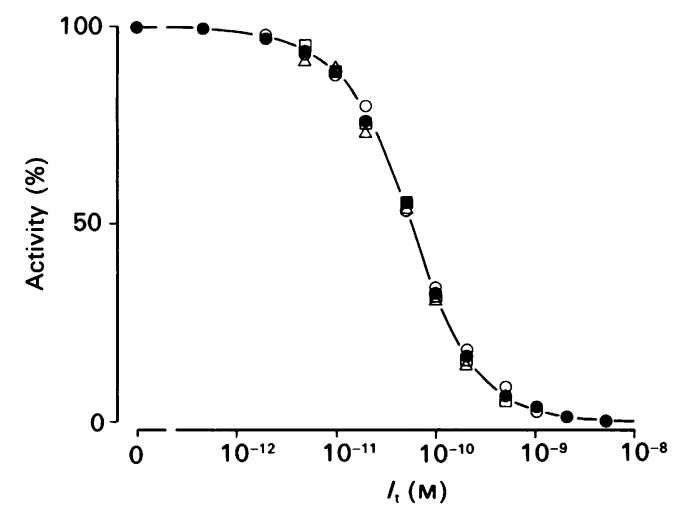

Fig. 5. Effect of changing the substrate ( $p N P P$ ) concentration on the dose-inhibition relationship for the type $2 \mathrm{~A}$ phosphatase

Experiments are similar to those shown in Fig. 1. The total concentration of okadaic acid applied is denoted by $I_{\mathrm{t}}$. The inhibitory effect of okadaic acid on the $p$ NPP phosphatase activity of the type $2 \mathrm{~A}$ phosphatase $\left(E_{\mathrm{t}}=50 \mathrm{pM}\right)$ was examined for various substrate concentrations, [ $p \mathrm{NPP}]: 0,1 \mathrm{~mm} ; O, 5 \mathrm{~mm} ; \square, 10 \mathrm{~mm} ; \triangle, 20 \mathrm{~mm}$. Each symbol represents the average of 4-5 values. Vertical bars indicating S.E.M. are omitted for clarity. The dose-inhibition relationship was not significantly altered by changing the substrate concentration over the concentration range of okadaic acid examined.

ance, and the kinetic constants, $K_{\mathrm{m}}$ and $V$, were estimated, by the direct linear plot, to be $4.8(3.9-5.5) \mathrm{mm}$ [median $(95 \%$ confidence limits)] and $233(217-255) \mu \mathrm{mol} / \mathrm{min}$ (units) per $\mathrm{mg}$ of protein respectively.

In the present dose-inhibition study for this $p$ NPP phosphatase activity, $E_{\mathrm{t}}$ was larger than the true dissociation constant for the inhibitor okadaic acid (see above). Therefore, in the experiments shown in Fig. 5, we examined the effect of changing the substrate ( $p$ NPP) concentration on the dose-inhibition relationship, in order to diagnose the mode of action of the inhibitor (see the Experimental section). The assays were carried out with a relatively low concentration $\left(E_{\mathrm{t}}=50 \mathrm{pM}\right)$ of the enzyme. The dose-inhibition relationship was not significantly altered over the range of the inhibitor concentration examined when the substrate concentration was changed from $1 \mathrm{~mm}$ to $20 \mathrm{~mm}$ (Fig. 5). Thus okadaic acid appears to act as a non-competitive
Table 2. Effect of okadaic acid on the kinetics of the $p$ NPP phosphatase activity of the type 1 phosphatase preparation

The dependence of the initial steady-state velocity on the substrate ( $p$ NPP) concentration (2.5-20 mM) was examined. A small amount ( $0.5 \mathrm{nM})$ of okadaic acid was added also for the control, in order to minimize the interference by contamination with type $2 \mathrm{~A}$ activity. The values of the Michaelis constant $\left(K_{\mathrm{m}}\right)$ and the maximal velocity $(V)$ determined by the direct linear plot are presented with $95 \%$ confidence limits (in parentheses). Okadaic acid (200 nM) caused a significant $(P<0.01)$ decrease in $V$, whereas it did not affect $K_{\mathrm{m}}$.

\begin{tabular}{lcc}
\hline $\begin{array}{l}\text { [Okadaic acid] } \\
\text { (nM) }\end{array}$ & $\begin{array}{c}K_{\mathrm{m}} \\
(\mathrm{mM})\end{array}$ & $\begin{array}{c}V \\
\text { (units/mg of } \\
\text { protein) }\end{array}$ \\
\hline 0.5 (control) & $16(13-19)$ & $180(164-201)$ \\
200 & $18(14-22)$ & $89(70-109)$
\end{tabular}

inhibitor. Unfortunately measurements at concentrations of $p$ NPP higher than $20 \mathrm{~mm}$ gave only poor results because of high background absorbance. However, the range seems to be wide enough to distinguish the mode of inhibition, as discussed below (see the Discussion section).

For the $p$ NPP phosphatase activity of the type 1 phosphatase, the dose-inhibition relationship was not affected by changing the enzyme concentration (see above). The effect of changing the substrate ( $p$ NPP) concentration in the range $2.5-20 \mathrm{~mm}$ on the initial steady-state velocity was examined. A small amount $(0.5 \mathrm{nM})$ of okadaic acid was added for the control, in order to minimize the interference by contamination with the type $2 \mathrm{~A}$ phosphatase activity (see above). The Lineweaver-Burk plot had a linear appearance in the concentration range $1 \mathrm{mM}<[p$ NPP] $<20 \mathrm{mM}$ for the result obtained in the presence of $200 \mathrm{nM}$ okadaic acid as well as for the control (result not shown). As given in Table 2 , the $V$ was decreased $(P<0.01)$ whereas the $K_{\mathrm{m}}$ was not significantly changed by okadaic acid, i.e. the inhibition was a non-competitive type.

\section{DISCUSSION}

Of the three types of protein phosphatase preparation examined in the present experiments, the type $2 \mathrm{~A}$ protein phosphatase preparation showed an especially high activity toward $p$ NPP (Table 1). The following observations strongly support the idea that the $p$ NPP phosphatase activity is intrinsic to type $2 \mathrm{~A}$ protein phosphatase and is not due to contamination by alkaline phosphatases. (i) The $p$ NPP phosphatase activity is unaffected by inhibitor 2, whereas it is strongly inhibited by okadaic acid, which has been shown to have no effect on alkaline phosphatases (Bialojan \& Takai, 1988). (ii) The sensitivity of the $p$ NPP phosphatase activity to okadaic acid apparently decreases when the enzyme concentration is increased, as has been reported for the phosphorylase $a$ phosphatase activity of type 2A phosphatase (Cohen et al., 1989). The dose-inhibition relationship and its shift caused by increasing the enzyme concentration are well described by the kinetic theory for ' tightly binding' inhibitors (see the Experimental section). From the kinetic analysis, the value of the dissociation constant for the interaction between the enzyme and okadaic acid, $K_{i}$, has been estimated to be as low as $32 \mathrm{pm}$. (iii) The molar concentration of the enzyme responsible for the $p$ NPP phosphatase activity estimated by the titration with okadaic acid is in close agreement with that of the type $2 \mathrm{~A}$ protein phosphatase calculated from the protein content and the molecular mass (Fig. 3).

When the molar concentration of the enzyme $\left(E_{\mathrm{t}}\right)$ is higher than that of the dissociation constant for the inhibitor $\left(K_{\mathrm{i}}\right)$, as is 
the case with the present experiments for the type 2A phosphatase, the Michaelis-Menten analysis of inhibition is not valid (Henderson, 1972; Williams \& Morrison, 1979). However, the mode of inhibition can still be diagnosed by examining the effect of changing the substrate concentration on the $K_{1}$ for relatively low concentrations of the enzyme (see the Experimental section). We have shown that the dose-inhibition relationship for the $p$ NPP phosphatase activity of the type $2 \mathrm{~A}$ phosphatase (50 pM) is not changed when the concentration of the substrate ( $p$ NPP) is increased from $1 \mathrm{~mm}$ to $20 \mathrm{~mm}$ (Fig. 5). This observation supports the idea that okadaic acid acts as a non-competitive inhibitor. Measurements with higher concentrations of $p$ NPP do not give reliable results because of high background absorbance (see the Results section). However, the concentration range of $p$ NPP in the present kinetic analysis seems to be wide enough to exclude the possibility that the inhibition might be competitive or uncompetitive. If okadaic acid was a competitive inhibitor, for which eqn. (11) applies, the value of $K_{0}$ would be estimated to be $28 \mathrm{pM}$ from the value of $K_{\mathrm{m}}(4.8 \mathrm{mM})$ in the absence of okadaic acid and that of $\operatorname{ID}_{50}(57 \mathrm{pM})$ for the dose-inhibition relationship obtained with $5 \mathrm{~mm}-p$ NPP. Therefore the value of ID $_{50}$ would increase from $35 \mathrm{pM}$ to $145 \mathrm{pM}$ as the substrate concentration is changed from $1 \mathrm{~mm}$ to $20 \mathrm{~mm}$ [see eqn. (11)]. If the inhibition was uncompetitive, the same change in the substrate concentration would result in a decrease in the $\mathrm{ID}_{50}$ from $170 \mathrm{pM}$ to $35 \mathrm{pM}$, as predicted by similar considerations based on eqn. (12). Given the level of experimental errors of the present results (Fig. 5), the changes in ID $_{50}$ would have been easily detected as shifts of the dose-inhibition curve.

However, it should be noted that small changes in the value of $K_{1}(s)$ are difficult to detect in dose-inhibition studies for tightly binding inhibitors, partly because $K_{\mathrm{i}}(s)$ can only indirectly be estimated by using eqn. (6). (The severity of the situation is intensified as $E_{\mathrm{t}} / K_{\mathrm{i}}$ becomes large. Note that it is not only the value of $\mathrm{ID}_{50}$ but also that of $E_{\mathrm{t}}$ which is subject to experimental errors.) For example, if okadaic acid acts as a mixed inhibitor on the type $2 \mathrm{~A}$ phosphatase ( $50 \mathrm{pM}$ ) and the ratio of $K_{1}$ to $K_{0}$ is 2.0 , then the change in substrate concentration from $1 \mathrm{mM}$ to $20 \mathrm{mM}$ will increase the $K_{\mathrm{i}}$ by $55 \%$ [from 25 pм to 40 pM; see eqn. (9)]. This relatively small change in $K_{\mathrm{i}}$ will result in a less than $30 \%$ increase in ID $_{50}$ [from $51 \mathrm{pM}$ to $65 \mathrm{pM}$; see eqn. (6)]. It is not easy to distinguish a change in a dose-inhibition relationship to this extent from experimental deviation. Further experiments are necessary to establish whether okadaic acid acts as a noncompetitive inhibitor or as a mixed inhibitor on the $p$ NPP phosphatase activity of type $2 \mathrm{~A}$ phosphatase. It has been reported that okadaic acid causes mixed inhibition for the protein phosphatase activities of a type $2 \mathrm{~A}$ phosphatase preparation (Bialojan \& Takai, 1988).

The $p$ NPP phosphatase activity of the type $2 \mathrm{~A}$ phosphatase has characteristics distinct from those of its protein phosphatase activities. Type $2 \mathrm{~A}$ phosphatase does not require any bivalent cation for activity towards its ordinary protein substrates, whereas it exhibits a 40-50-fold higher $p$ NPP activity in the presence of $30 \mathrm{mM}-\mathrm{Mg}^{2+}$ than in its absence (see the Results section). The optimal $\mathrm{pH}$ for activation is in the range 8.0-8.5 for $p$ NPP phosphatase activity of the type $2 \mathrm{~A}$ phosphatase, whose protein phosphatase activities have a maximum at $\mathrm{pH} 6.5-7.5$. Li (1979) and Li \& Chan (1981) have described similar differences between the $p$ NPP phosphatase activity and the phosphorylase $a$ phosphatase activity of their ' $M_{\mathrm{r}}=35000$ phosphatase' preparations (see also $\mathrm{Li}, 1982$ ). This is not unexpected, because their preparations appear to be the catalytic subunit of type $2 \mathrm{~A}$ phosphatase, as judged from the purification procedure.

The type 1 phosphatase preparation exhibits a much lower $p$ NPP phosphatase activity than does the type $2 \mathrm{~A}$ phosphatase
(Table 1). This $p$ NPP phosphatase activity is also inhibited by okadaic acid. The dose-inhibition relationship is fitted by a simple Hill function which is not significantly altered by changing the enzyme concentration from 2 to $20 \mu \mathrm{g}$ of protein $/ \mathrm{ml}$. The ID $_{50}$ is $145 \mathrm{nM}$ (Fig. 4), which is similar to the values reported for the protein phosphatase activities of type 1 phosphatase (Bialojan \& Takai, 1988). Kinetic analyses have shown that the mode of inhibition is non-competitive for both the protein phosphatase activities (Bialojan \& Takai, 1988) and the $p$ NPP phosphatase activity (see the Results section). These observations are in support of the notion that the type 1 phosphatase also has an intrinsic $p$ NPP phosphatase activity. Interestingly, the $p$ NPP phosphatase activity is only very weakly suppressed by $100 \mathrm{nM}$ inhibitor 2, which nearly abolishes the PMLC phosphatase activity. Strålfors et al. (1985) have reported that inactivation of some forms of type 1 phosphatase by inhibitor 1 or inhibitor 2 is time-dependent, half-maximal inhibition requiring a $10 \mathrm{~min}$ preincubation with these proteins. However, no progressive suppression of $p$ NPP phosphatase occurs when inhibitor 2 is applied for longer than $15 \mathrm{~min}$ (see the Results section). The reason for the resistance of the $p$ NPP phosphatase activity to inhibitor 2 is unknown from the present experiments. Foulkes et al. (1983) have shown that inhibitor 2 acts as a competitive inhibitor to the protein phosphatase activity of type 1 phosphatase. One possibility is therefore that inhibitor 2 may bind to a site on phosphatase molecules that resides in the binding site for protein substrates, but does not involve the catalytic centre, which is accessible to $p$ NPP even in the presence of inhibitor 2 because of the small molecular size of $p$ NPP.

The type $2 \mathrm{C}$ phosphatase preparation has only a very weak but still measurable $p$ NPP phosphatase activity, which is absolutely dependent on $\mathrm{Mg}^{2+}$. Since this activity is not affected by up to $10 \mu \mathrm{M}$-okadaic acid, it is not ascribable to contamination by type $2 \mathrm{~A}$ and/or type 1 phosphatase. However, further experiments are necessary to exclude the possibility that this activity may be due to contamination by alkaline phosphatases.

Okadaic acid is known to be one of the most important causative agents of the seasonal diarrhoetic poisoning resulting from ingestion of scallops, mussels or other types of clam (Yasumoto et al., 1985). Several methods using h.p.l.c. (Lee et al., 1987) or monoclonal antibody against okadaic acid (Levine et al., 1988; Usagawa et al., 1989) have been described for the assay of okadaic acid in extracts of the mid-gut gland of clams. Such methods require some tedious procedures, and the minimum amount of okadaic acid detected thereby is reportedly in the order of nanograms. It should be pointed out that much smaller amounts of okadaic acid in an extract can, at least theoretically, be assayed with high specificity by examining the ability of the extract to inhibit a definite concentration of type $2 \mathrm{~A}$ phosphatase. This potential method is also attractive from the point of view of pathogenesis of shellfish poisoning, because the diarrhoetic symptom is probably related to inhibition of protein phosphatase(s) in absorptive intestinal cells (Cohen, 1989; see also Terao et al., 1986). For the purpose of assaying okadaic acid as the causative agent of shellfish poisoning, $p$ NPP seems to be a useful substrate, because the activity of type $2 \mathrm{~A}$ phosphatase toward this commercially available substrate is exceedingly high and therefore it can easily and accurately be determined with an ordinary spectrophotometer.

Part of the work was done while A.T. was working in the laboratory of Professor J.C. Rüegg (Heidelberg) with the technical assistance of Ms. Monika Troschka. We thank Professor Hans-Dieter Söling (Göttingen) and Professor Philip Cohen (Dundee) for kindly reading the manuscript. Valuable technical assistance by Mr. Ken Hasegawa is also gratefully acknowledged. This work was partly supported by a Grant-inAid from the Ministry of Education of Japan. 


\section{REFERENCES}

Bialojan, C. \& Takai, A. (1988) Biochem. J. 256, 283-290

Cohen, P. (1989) Annu. Rev. Biochem. 58, 453-508

Cohen, P. \& Cohen, P. T. W. (1989) J. Biol. Chem. 264, 21435-21438

Cohen, P., Nimmo, G. A. \& Antoniw, J. F. (1977) Biochem. J. 162, 435-444

Cohen, P., Foulkes, J. G., Holmes, C. F. B., Nimmo, G. A. \& Tonks, N. K. (1988) Methods Enzymol. 159, 427-437

Cummins, P. \& Lambert, S. J. (1986) Circ. Res. 58, 846-868

Eisenthal, R. \& Cornish-Bowden, A. (1974) Biochem. J. 139, 715-720

Foulkes, J. G., Strada, S. J., Henderson, J. B. \& Cohen, P. (1983) Eur. J. Biochem. 132, 309-313

Goldstein, A. (1944) J. Gen. Physiol. 27, 529-580

Haystead, T. A. J., Sim, A. T. R., Carling, R. C., Honnor, R. C., Tsukitani, Y., Cohen, P. \& Hardie, D. G. (1989) Nature (London) 337, 78-81

Henderson, P. (1972) Biochem. J. 127, 321-333

Hescheler, J., Mieskes, G., Rüegg, J. C., Takai, A. \& Trautwein, W. (1988) Pflügers Arch. 412, 248-252

Hollander, M. \& Wolfe, D. A. (1973) Non-Parametric Statistical Methods, pp. 27-38, 209-217 and 269-271, John Wiley and Sons, New York

Huang, F. L. \& Glinsmann, W. H. (1976) Eur. J. Biochem. 70, 419-426

Ingebritsen, T. S. \& Cohen, P. (1983) Eur. J. Biochem. 132, 255-261

Lee, J. A.,Yanagi, T., Kenma, R. \& Yasumoto, T. (1987) Agric. Biol. Chem. 51, 877-881

Levine, L., Fujiki, H., Yamada, K., Ojika, M., Gjika, H. B. \& van Vunakis, H. (1988) Toxicon 27, 1327-1330

Li, H.-C. (1979) Eur. J. Biochem. 102, 363-374

Received 2 August 1990/26 October 1990; accepted 6 November 1990
Li, H.-C. (1982) Curr. Top. Cell. Regul. 21, 129-174

Li, H.-C. \& Chan, W. W. S. (1981) Arch. Biochem. Biophys. 207, 207-281

Lowry, O. H., Rosebrough, N. J., Farr, A. L. \& Randall, R. J. (1951)

J. Biol. Chem. 193, 265-275

McGowan, C. G. \& Cohen, P. (1987) Eur. J. Biochem. 166, 713-722

Ngai, P. K., Carruthers, C. A. \& Walsh, M. P. (1984) Biochem. J. 218, 863-870

Pallen, C. H. \& Wang, J. H. (1983) J. Biol. Chem. 258, 8550-8553

Porter, W. R. \& Trager, W. F. (1977) Biochem. J. 161, 293-302

Snedecor, G. W. \& Cochran, W. G. (1980) Statistical Methods, 7th edn., pp. 143-160, 175, 191, 385-388 and 407-409, Iowa State University Press, Ames

Strålfors, P., Hiraga, A. \& Cohen, P. (1985) Eur. J. Biochem. 149, 295-303

Tachibana, K., Scheuer, P. J., Tsukitani, Y., Kikuchi, H., van Eugen, D., Clardy, J., Gopichand, Y. \& Schmitz, F. J. (1981) J. Am. Chem. Soc. 103, 2469-2471

Takai, A., Bialojan, C., Troschka, M. \& Rüegg, J. C. (1987) FEBS Lett. 217, 81-84

Takai, A., Troschka, M., Mieskes, G. \& Somlyo, A. V. (1989) Biochem. J. 262, 617-623

Terao, K., Ito, E., Yanagi, T. \& Yasumoto, T. (1986) Toxicon 24, 1141-1151

Tung, H. Y. L., Resink, T. J., Shenoiikar, S. \& Cohen, P. (1984) Eur. J. Biochem. 138, 635-641

Usagawa, T., Nishimura, M., Itoh, Y., Uda, T. \& Yasumoto, T. (1989) Toxicon, 27, 1323-1330

Williams, J. W. \& Morrison, J. F. (1979) Methods Enzymol. 63, 437-467

Yasumoto, K., Murata, M., Ohshima, Y., Sano, M., Matsumoto, G. K. \& Clardy, J. (1985) Tetrahedron 41, 1019-1025 